\title{
Role of Agricultural Finance in Producing Food Crops
}

\author{
Elgilany A. Ahmed ${ }^{1, *}$, Hamid H. M. Faki ${ }^{2}$, Abubkr Hussein ${ }^{3}$ \\ ${ }^{1}$ School of Social Sciences, University Sains Malaysia, Pulau, Penang, 11800, Malaysia \\ ${ }^{2}$ Agricultural Economics Research and Policy Center, Agricultural Research Corporation, 1111, Sudan \\ ${ }^{3}$ Development Studies and Research Institute, University of Khartoum, 1111, Sudan
}

\begin{abstract}
This paper presents a comparative analysis of current trends in financing of main food crops in the public irrigated schemes of the River Nile State (RNS) and analyzes various agricultural credit mechanisms that have been used in the State. It aims to explore the plausible framework in order to increase agricultural outputs and farmers returns in the area of study. It was on this basis the research undertook Elzeidab scheme of RNS as a case study. Primary data was collected by using structured questionnaires for (70) randomly selected respondents from Elzeidab scheme. Statistical analysis has been employed to assess current situation in financing of main food crops in the scheme. The paper unveiled that these crops are described as low value crops. Also, it revealed that the formal finance is characterized as inefficient to serve the target part of farmers while the informal one is limited to cover the farmer' expenditures. The paper concluded that, the credit market in RNS is not well developed and the majority of households (93\%) have no access to formal financial institutions. This allows the recommendation to be drawn that improving finance institutions will enable the tenants to improve their farm resources use.
\end{abstract}

Keywords Agricultural Finance, Food Crops, River Nile

\section{Introduction}

Despite recent increased international awareness of the importance of agriculture as a generator of income, employment, foreign exchange and tax revenues as well as its association with poverty reduction and the preservation of natural resources, there is still a need for increased awareness of the important role that agricultural finance for development plays in the above issues. Ruben (2009) mentioned that the great potential of agricultural finance in issues of food security, poverty reduction, and preservation of natural resources must be emphasized in order to overcome the perpetual under-investment in public agricultural production in developing countries.

Agricultural finance in Sudan is considered as one of the main factors affecting food crop production, it faced numerous obstacles regarded the provision of short and long-term agricultural credit mainly the low devoted percentage for agricultural sectors injected through the agricultural finance institutions and it continues to show steady but slow progress, though there is wide variation amongst the various branches with regard to performance and efficiency. These policies reflected in large number of farmers particularly in the irrigated and mechanized rain-fed sectors con tinue complaining of agricultural finance mechanism.

* Corresponding author:

elgilanya@yahoo.com (Elgilany A. Ahmed)

Published online at http://journal.sapub.org/ijaf

Copyright (C) 2012 Scientific \& Academic Publishing. All Rights Reserved
Furthermore, the expected repayment by farmers was under estimation and led to classify high portion of farmers as a defaulters. Faki et al. (2003) stated that, despite the government stressed to solve credit constraints by devoting high percentage macro-finance for the agricultural sector, the majority of the farmers are suffered of shortage or/and limited of credit resources, that is the total amount of finance provided for this sector only $5 \%$ of the total cost of production and that led to a high percentage $53 \%$ of defaulters failed to repay about $77 \%$ of the total agricultural finance. $\mathrm{Nu}-$ merous researches mentioned that the RNS has been assumed to have a comparative advantage with perennial, cereal, corms and legumes food crops production namely, wheat, faba bean, chickpea, dry beans, onions, vegetables, spices, sorghum, maize, potatoes and fodder beside some perennial crops. All the mentioned field crops are grown in both private and public irrigated schemes of the state, but the public ones are regarded the main suppliers for these crops according to its areas and the highly number of tenants. The production of these crops based mainly on family members and distinguished by using low level of commercial physical agricultural inputs. Both formal and informal sources of finance are existed in the area of study. The formal finance usually provided by governmental institutions and banks (i.e. agricultural ministries, ABS), while the informal one implies relatives, merchants and others beside some farmers depend on their own resources. The paper stressed on the dominant agricultural financial system in the public irrigated schemes of RNS due to its importance in achieving the aims of agricultural development which could summarized in the stabil- 
ity for the suitable farm size with using economy of scale, increasing production efficiency, enhancing the adoption of economical change, technologies and innovations., passing seasonal fluctuations related to the income, expenditure and unfavorable weather, possessing the fixed assets in short period compared to individual saving. Unfortunately, in RNS irrigation started much later than intended because cash were not available to buy water inputs (i.e. fuel) for the scheme pumps. Farmers frequently complain that they are forced to sell their produce to traders for a price below the floor price as they have urgent cash requirements. Credit and finance for traditional agriculture remains, understandably, at a very low level, with problems of non-viable collateral, small loan levels, geographical distance and the logistics of recovery. Attempts have been made to form cooperatives but few have had any success. The paper undertook Elzeidab public irrigated scheme as a case study to implement the study. The farm management is fully under the tenants' control, while the government is considered as a maker of agricultural policies, a water seller, and provider agricultural credit. Finally, the farmers wish that the national credit situation as soon as to be improved with the recent initiation, following the signing of the north-south peace agreement, of a microfinance project involving the World Bank, the Ministry of Finance and the Central Bank, and a sum of USD 269 million over a period of six years.

\section{Methodology}

This study was carried in Elzeidab public irrigated scheme of RNS. The crops are commonly produced under pump irrigation from the River Nile to some extend as well as from underground water. The farming system of the RNS is characterized mainly as not full-mechanized system, the winter season is considered the main season for producing cereal, corms and legume crops, recently, the State enlarged animal production activities and oil crops. The study depends on both primary and secondary data. Primary data was collected through direct personal interviewing by using structured questionnaires for (70) randomly selected respondents through probability proportional method from Elzeidab public irrigated scheme of RNS as a case study in season 2005/06. The secondary data was collected from its relevant sources. The analytical techniques a descriptive statistical analysis has been employed through the computer software program (SPSS) software programs has been employed by using frequency, distribution, and graphical analysis to achieve the objectives of the study. The data collected consisted mainly to the sources and value of finance, mechanism of providing and repayment of finance, type of finance.

\section{Results and Discussion}

The formal financial system provides only small parts of credit used by farmers. Therefore, most of farmers seek other informal sources of finance. Loans extended by friends and relatives, mostly without interest, constitute the non-commercial segment. In the commercial segment a range of people like traders, agricultural and professional money lenders operate (Ijami, 1994). Faki et al. (2003) mentioned that self-finance is regarded as the main source of agricultural finance in River Nile State and it covered about $67 \%$ of the total available finance, while 'Shail' system formed $17 \%$ as a second source of finance. Formal credit through Agricultural Bank of Sudan contributed only with $2 \%$ and $10 \%$ for sorghum and faba bean respectively.

\subsection{Scenarios of Agricultural Finance Mechanism in River Nile State}

The scenarios of finance story and its evolution is difficult to be in its complete profile due to the very little information under which commercial and food crops production growth in Sudan have been documented. The evolution of finance at the local level of RNS began since 1920s of the first half of the last century, it has witnessed the establishment of the major agricultural institutions in the Northern Region Sudan namely: Ministry of Agriculture and Natural Resource, Northern Agricultural Production Corporation Schemes (NAPCS) and Agricultural Bank of Sudan (ABS) as main sponsors of agricultural production in the region. The land cultivation is handled by three sections: Private (62\%), cooperatives $(22 \%)$ and public (16\%). NPACS was directly responsible for the public schemes in the region, management and provide most of the required inputs and services only for cotton production, under Joint Account System (JAS), while production of other field crops (i.e. wheat, faba bean) were produced under fixed rate relationship where the farmers pay a fixed water charges per feddan according to the type of crop (field, perennial) for the scheme administration who responsible to provide irrigation water and field water supervision. The second potion was the share cropping system, the whole idea was to share the crop produced equally between the pump owner and the farmer. The share cropping system based on sharing production cost and returns to achieve mutual benefits for partnership. While the evolution of finance at the international level, a Sudan-USA program was established under the mutual security act with economic and technical assistance from the U.S in (1958). The establishment of educational facilities and of an agricultural services as among the most prominent efforts of the missions in which the Sudanese department of agriculture was provided with technicians who worked in close collaboration with Sudanese counterpart. In (1964-1979) as a result of that mission, statistics relating to present age of cropping under Nile pump irrigation based on winter cropping (i.e. cereal, legume crops) illustrate that the most significant shift has been from subsistence cropping of cereal to the commercial (cash) cropping of pulses, where the area under cash crops increased significantly from $17 \%$ in (1964/1965) to $27 \%$ in (1977/1978). Furthermore, the In- 
ternational Fund for Agricultural Development (IFAD) has signed a loan agreement with the government of Sudan to rehabilitate agricultural scheme in the Northern Region of Sudan. Projects were established to improve irrigation systems, transfer of technology development, and attracted collaboration inputs from institutes in Sudan as well as from international organization. Collaboration and the Sudan government were successful to achieve their collaborated program successfully. The development programs continued (1979-1995), the Nile Valley Project (NVP) undertook by IFAD and the International Center for Agricultural Research in Dry Area (ICARDA), as extension of IFAD projects. The NVP considered as one of the major programs specified on wheat and legume crops, it began in (1979) the executive board of IFAD approved a technical assistance grant equivalent to US\$ 3 million to be given to ICARDA for applied research on the mentioned crops. Finally, the efforts of U.S.A aid, IFAD, ICARDA collaborated with Sudanese government produced a vast evolution particularly on agricultural finance and main food crops production.

\subsection{Capital Circuit of Main Food Crops in RNS}

Food crops are considered as the most important annually produced crops with respect to its contribute to farm sustainability and farmers income. The farmers in the area of study usually pass through different stages to achieve their harvests. During these stages, sometimes they live comfortably and possess an excess in basic needs after harvest, while they live in balanced period which is described as an idle period with less or no farm activity, and they ended these stages facing a drastically periods characterized with shortage of food and/or money at the tail of season.

These stages occurred through a year and can be summarized in three periods namely, surplus, balanced and deficit periods as illustrated in Figure (1).

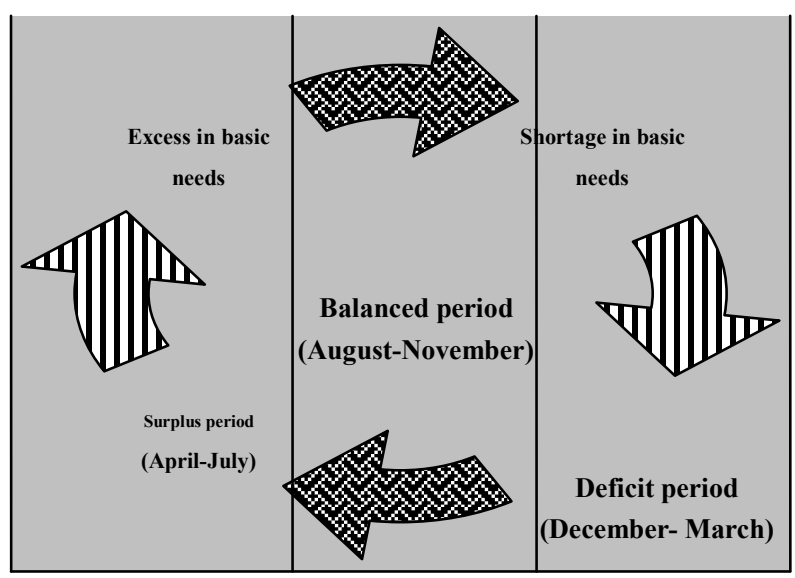

Figure (1). Capital circuit of main food crops in River Nile State.

\subsubsection{Surplus Period}

The surplus period usually occurs during April to July. In this case the main harvesting season is once per year namely winter season under the irrigated pump schemes of RNS. The majorities of the schemes tenants sell their crops immedi- ately after harvest and gain returns pending on the marketable surplus of food crop quantities. The paper revealed that most of the farmers $57 \%$ trade their crops to local traders who usually regarded as money lenders (in kind or/and in cash) (see Table (1)).

Table (1). Distribution of surveyed tenants according to main markets.

\begin{tabular}{|l|l|l|}
\hline Market & Number & Percentage \\
\hline Elzeidab & 24 & 34 \\
\hline Elaliab & 01 & 2 \\
\hline Elketiab & 01 & 2 \\
\hline Eldamer & 01 & 2 \\
\hline Local traders & 40 & 57 \\
\hline Atbara & 02 & 2 \\
\hline Khartoum & 01 & 1 \\
\hline Total & 70 & 100 \\
\hline
\end{tabular}

Local traders are considered as important source of informal finance; they financing farmers by agricultural inputs, money and consumption commodities. Thus, the first decision took by farmers after harvest to sell their products to the lender traders so as to cover their debts. The crop returns are created the surplus period and it can be described that the cash inflow and out flow balance is usually positive but are not sufficient to establish new investment in a farm, hence, the farmers in this period usually idle and stagnant. Elfeil (1993) summarized the farm and the off farm incomes are found to be mostly used for consumption purposes and very rarely invested in the farm. The paper observed that tenant inn the area of study was considered as an expert in Northern Sudan due to his capability to organize a future plan for distribution his products. The field data (Table 2) revealed that the actual quantities of main food crops to be sold were $88 \%$ of the total production. About $77 \%$ of the total food crop production was sold immediately after harvest, while the remaining quantities of $13 \%$ went to storage. Table (2) also shows that grain and legume crops were distributed for direct sale after harvest and storage, while vegetables, spices and potatoes were sold immediately after harvest due to lack storages and inadequate markets. The structure of marketing in the RNS has a hierarchical structure where institutions of different types are involved.

\subsubsection{Balanced Period}

The balanced period considered as a second period, in the area of study, it lies on the dead season from August to November. In this period the farmers depend on their saved money or/and stored crops from the previous period to continue expenditure for household consumption, the major characteristic of this period that the cash inflow and out flow balance is usually negative and the farm activities continue idling. Thus, the farmers in this period plan more than work, they devote $32 \%$ of the stored amounts as seeds for the next season and $26 \%$ for household consumption, while the future sale quantities was found to be $42 \%$ as illustrated in Table (2). 
Table (2). Distribution of main crop quantities for surveyed tenants.

\begin{tabular}{|l|c|c|c|c|l|}
\hline \multicolumn{1}{|c|}{ Crop } & $\begin{array}{l}\text { Prodution } \\
(\mathrm{kg} / \text { fed })\end{array}$ & $\begin{array}{c}\text { After } \\
\text { Harvest } \\
\text { (ale }(\mathrm{kg})\end{array}$ & $\begin{array}{c}\text { H.H } \\
\text { consump- } \\
\text { tion }(\mathrm{kg})\end{array}$ & $\begin{array}{c}\text { Seeds of } \\
\text { next } \\
\text { season }(\mathrm{kg})\end{array}$ & $\begin{array}{l}\text { Future } \\
\text { ale (kg) }\end{array}$ \\
\hline Wheat & 2461.5 & 1554.48 & 181.44 & 336.96 & 388.62 \\
\hline Faba bean & 1739.7 & 1161.36 & 100.8 & 187.2 & 290.34 \\
\hline Chickpea & 387 & 291.6 & 8.82 & 16.38 & 72.9 \\
\hline Dry bean & 1080 & 720 & 63 & 117 & 180 \\
\hline Onions & 4820.4 & 3568.32 & 126 & 234 & 892.08 \\
\hline Spices & 2999.7 & 2999.7 & - & - & - \\
\hline Vegetbles & 1491.78 & 1480,89 & 10.89 & - & - \\
\hline Sorghum & 4072.5 & 2422.8 & 365.4 & 698.6 & 605.7 \\
\hline Maize & 1845 & 1080 & 173.25 & 321.75 & 270 \\
\hline Potatoes & 4000 & 4000 & - & - & - \\
\hline Fodder & 3550 & - & 3350 & - & - \\
\hline
\end{tabular}

\subsubsection{Deficit Period}

The deficit period starts from the beginning of December and continues to the end of March. In this period farmers continue expenditure in two main items namely, establishment of farm crops and household consumption. The farmers in this period always suffer of shortage of money due to the expenditure of remained saved money or/and stored crops in one hand, on the other hand, the commodities required for household consumption. The major characteristic of this period are absence of cash inflow and high expenditures than the other previous period, shortage of farm operation requirements affect crop productivity. The farmers are dependent up on credit for meeting their immediate cash needs for different agriculture operation as well as, for household consumption. In this period most of the farmers depend on their own source (sale of assets and animals) to finance their crops. On the other sources of credit such as "Shail" system and governmental institutions (i.e. State Ministry of Agriculture and Agricultural Bank of Sudan) (see Figure (2).

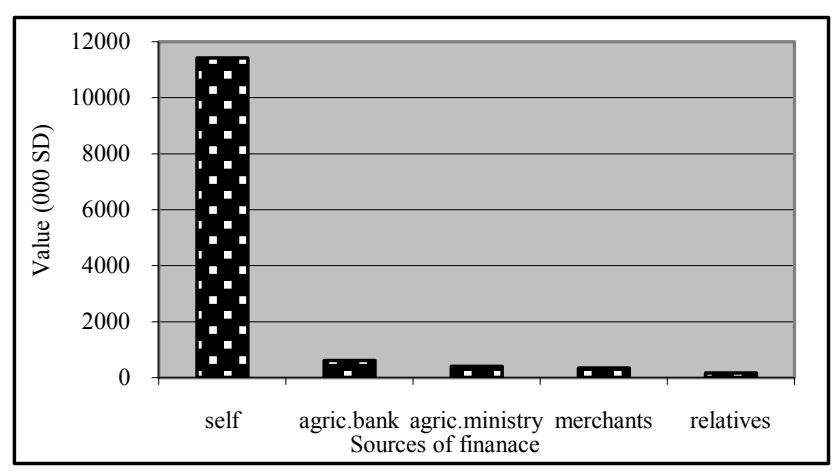

Figure (2). Prevailed sources of finance in Elzeidab scheme.

\subsection{Yield and Yield Gap of Food Crops in the Scheme}

To achieve socio-economic development objectives in a country well developed, effective and efficient agricultural credit system is needed. Finance is an instrument to simplify the temporarily transfer of purchasing power from one individual or institution to another. However, credit provides the base for increased productivity through specialization of function (Babiker, 2002). The crop combination adopted by the scheme's tenants is as illustrated in Table (3). From Table (3) the average crop yields achieved by Elzeidab sur- veyed tenants were generally low when compared by research yields reported by the Agricultural Research Corporation (ARC). Yield gaps of $47 \%$ and $81 \%$ apply for dry bean and vegetable crops, respectively, indicated that much potential gap exists to increase the scheme's yields of seasonal crops.

Table (3). Average farm area, yield and production of seasonal crops of surveyed tenants in the scheme as compared with ARTC yields.

\begin{tabular}{|c|c|c|c|}
\hline Crops & Yield (kg/fed) & $\begin{array}{c}\text { ARTC yield } \\
(\mathrm{kg} / \mathrm{fed})\end{array}$ & $\begin{array}{c}\text { Yield } \\
\text { Gap \% }\end{array}$ \\
\hline Wheat & 676 & 2000 & 66 \\
\hline Faba bean & 489 & 1500 & 67 \\
\hline Chickpea & 414 & 1250 & 67 \\
\hline Dry beans & 54 & 12000 & 55 \\
\hline Onions & 2880 & 1200 & 76 \\
\hline Spices & 63 & $\mathrm{Na}$ & $\mathrm{Na}$ \\
\hline Vegetables & 1853 & 10000 & 81 \\
\hline Sorghum & 1005 & 1700 & 41 \\
\hline Maize & 855 & 1700 & 50 \\
\hline Potatoes & 4000 & 10000 & 60 \\
\hline Fodder & 4000 & 2000 & 80 \\
\hline
\end{tabular}

\subsection{Current Situation of Agricultural Finance}

The research unveiled that formal finance in the River Nile State usually comes from Agricultural Bank of Sudan and State Ministry of Agriculture. The form of finance is often in kind with small percentage in cash. Formal finance can be described as insufficient to meet the actual cost requirements for farm operations. On the other hand, the informal finance is regarded as main sources of financing the main food crops in the study area (Table $4 \&$ Figure 3 ).

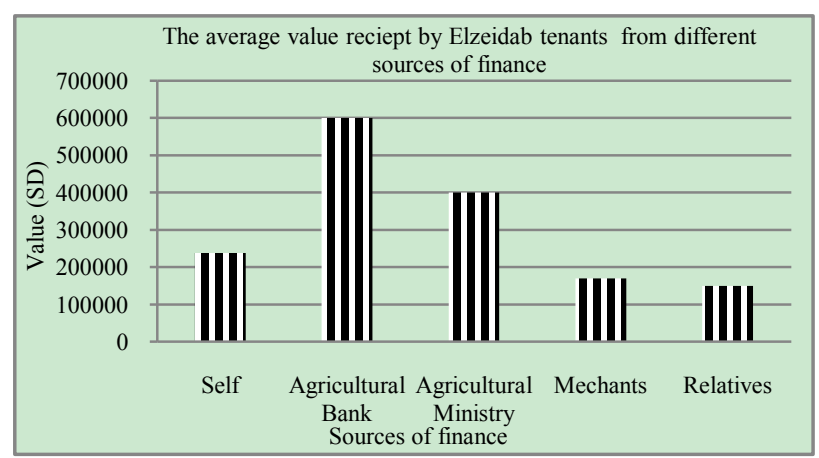

Figure (3). Average value provided by the main financial sources.

From Table (4) illustrates that $93 \%$ of surveyed tenants have to depend on their own resources of about SD 2379 for a farm, while the other informal financing sources represented 2.8\% from village merchants (about SD 170,000) and $1.4 \%$ for relatives (SD 50,000). The study revealed that both of the formal sources of finance mentioned above provided means for only a small percentage $1.4 \%$ of the total respondents. The average value provided by ABS and MAS were found to be SD 600,000 and SD 400,000 respectively, as illustrated in Figure (3).

Formal finance of main field crops whereby the ABS and agricultural ministry, a small number of farmers received physical inputs (i.e. fuel, seeds, land preparation, harvesting ...). A large number of farmers were unable to buy the 
these inputs at the proper time and reasonable price to capture the season because of lack of funding thus a valuable opportunity will pass under knees of farmers to obtain food crop harvests and their returns.

Table (4). Average value by different financial sources in RNS.

\begin{tabular}{|c|c|c|c|c|c|}
\hline $\begin{array}{c}\text { Source of } \\
\text { finance }\end{array}$ & $\begin{array}{c}\text { Average } \\
\text { value } \\
\text { '000'SD }\end{array}$ & $\begin{array}{c}\text { Time of } \\
\text { received }\end{array}$ & $\begin{array}{c}\text { Time of } \\
\text { repayment }\end{array}$ & $\begin{array}{c}\text { No. of } \\
\text { tenants }\end{array}$ & $\begin{array}{c}\text { Tenants } \\
(\%)\end{array}$ \\
\hline Self-finance & 2.379 & - & - & 55 & 93 \\
\hline ABS & 6000 & Nov. & May & 01 & 01.4 \\
\hline MAS & 400 & Dec. & April & 01 & 01.4 \\
\hline Merchant & 170 & Nov. & April & 02 & 02.8 \\
\hline Relatives & 150 & Oct. & April & 01 & 01.4 \\
\hline
\end{tabular}

\subsection{Finance of Perennial Crops in Elzeidab Scheme}

Historically, most of the perennial crops have been farmed in the RNS for hundreds of years ago. They provide options for income diversification and pathways out of poverty. Many Studies consistently show that the ratio of benefits to costs for fruit and vegetable crops is two times higher than the corresponding ratio for predominant cereals and pulses. Perennial crops in RNS are well-established and economically important products that make significant contribution to livelihoods in the irrigated farming systems (Figure 4). They include citruses, mango, guavas, date palm and alfalfa crops. A major obstacle to expanding and realizing the potential of perennial crops is the high cost of establishing new plantations and the recurrent cost of financing crops for the four to five years that are generally required before yields and revenues become significant. For the small, poor farmer, these costs may be beyond reach and not sustainable without external subsidies or other support from chain partners. The surveyed tenants of the scheme reported that the formal financial system was absent, and they depend on their resources totally for financing their crops by high amount of money as mentioned in Table (5) and figure (4).

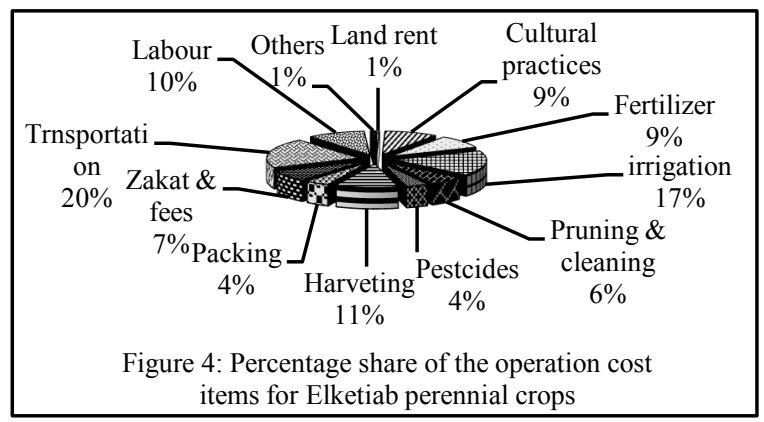

Figure (4). Percentage shares of the variable cost components for the perennial crops.

\subsection{Income Sources of the Surveyed Tenants}

Farmers may receive income from many sources, but the most common source is the sale of produced crops and livestock and other products raised or bought for resale. Off-farm income is still one of the principal options for Elzeidab tenants to meet their farm and household expendi- tures. Farm income under study reflects the economic status of Elzeidab surveyed tenants.

Table (5). Total variable costs of the perennial crops produced in Elzeidab scheme for the surveyed tenants, season 2005/2006 (SD/fed).

\begin{tabular}{|c|c|c|c|c|c|}
\hline $\begin{array}{c}\text { Crops } \\
\text { Items }\end{array}$ & Date & Citrus & Mango & Guava & Alfalfa \\
\hline $\begin{array}{c}\text { Total variable } \\
\text { cost }\end{array}$ & 139224.49 & 311704.4 & 203119.99 & 158506 & 147549.14 \\
\hline
\end{tabular}

The average total farm income was assessed as a summation of farm incomes from different farm activities and off-farm income from different sources. The results showed that the surveyed tenants seek off-farm opportunities due to their weak capabilities to face expenditure requirements of production seasons in addition to their household expenditures. Furthermore, the returns of agricultural activities became insufficient to cover the basic needs of their lives.

The main off-farm sources in study area are mainly remittances and contributions of the family members, formal employment, trade, and other off-farm private activities as mentioned in Table (6).

Table (6). Distribution of income sources of Elzeidab tenants'.

\begin{tabular}{|l|c|c|c|}
\hline Source of income & Value (SD) & $\%$ & $\%$ of total \\
\hline Source of farm income: & 437528.7 & 32 & \\
\hline$\quad \quad$ Seasonal crops returns & 786154.2 & 56 & \\
- Perennial crops returns & 158333.3 & 12 & \\
\hline Total average farm income & 1382016.02 & 100 & 64 \\
\hline Total average off-farm income & 639230.77 & & 36 \\
\hline Total average income of tenants & 2021246.79 & & 100 \\
\hline
\end{tabular}

Table (7). Distribution of sources of off-farm income for surveyed tenants.

\begin{tabular}{|c|c|c|}
\hline $\begin{array}{c}\text { Source of } \\
\text { off-farm income }\end{array}$ & No. of tenants & Value (SD) \\
\hline Formal job & 13 & 430461.54 \\
\hline Trading & 3 & 573333.33 \\
\hline Private work & 7 & 1392857.1 \\
\hline Remittances & 1 & 389000 \\
\hline Other & 2 & 195000 \\
\hline
\end{tabular}

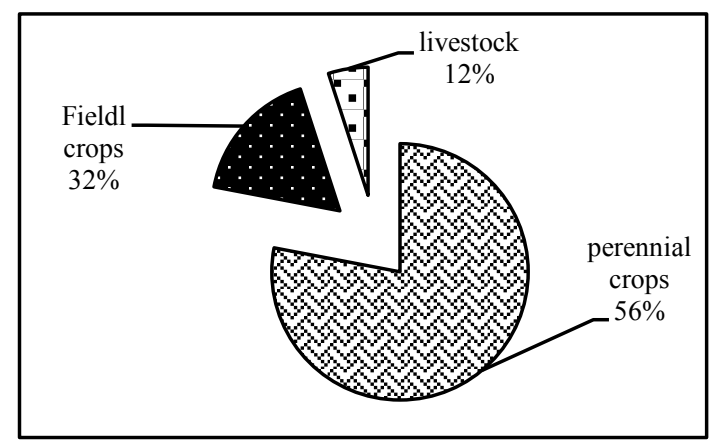

Figure (5). Distribution of farm income sources for the surveyed tenants.

The results in Table (6) revealed that $37.5 \%$ of Elzeidab tenants earned off-farm income beside their farm income, while 62.5 of the total surveyed tenants relied only on the farm returns. The average annual off-farm income was found to be SD 639231 representing $36 \%$ of the total tenant's incomes. Table (7) shows the detailed sources of off-farm 
incomes.

Table (7) shows that the tenant's private work had the highest value. On the other hand, the farm income distribution depicted in Figure (5) shows three main sources, namely seasonal crops, perennial crops and livestock. The shares of the these sources were respectively $56 \%, 32 \%$, and $12 \%$, while the total annual farm income gained by the tenants was SD 1382016 forming $64 \%$ of total income of tenants.

\section{Conclusions and Policy Implication}

This paper explore some of the findings of the field survey for Elzeidab area in RNS, and it described role of agricultural finance for producing main food crops in the public irrigated schemes of the River Nile State and conclusion drawn obtained from numerous analytical tools found that:

(1) the farmers in the area of study usually pass through different stages to achieve their harvests indicating irrationally allocation of their time and resources due to lack of awareness about investing in dead season and saving behavior (2) the financial capacities of tenants were very low returns and they affect their saving and the production of food crops (3)most of the crops under study usually sold immediately after harvest at very low farm gate prices, the reason that obliged farmers to sell immediately after harvest are the need for cash (4) Yields of the food crops in the area of study were lower when compared with average research yields (5) Perennial crops in RNS are well-established and economically important products. A major obstacle to expanding and realizing the potential of perennial crops is the high cost of establishing new plantations and the recurrent cost of financing crops for the four to five years that are generally required before yields and revenues become significant particularly for small poor farmers. Furthermore the finance for these crops is absent in the area of study. (5) Very low income characterizes the majority of field food crops and they achieved only $32 \%$ of the farm (6) Off-farm income was very important source for the surveyed tenants to improve their livelihood that $37.5 \%$ of Elzeidab tenants earned off-farm income beside their farm income (7) self-finance is regarded as the main source of agricultural finance in River Nile State and $93 \%$ of the surveyed tenants depend on their own resources (8) The unavailability of formal finance and limited informal finance as well as high cost of food crops production are usually decreasing yield and farmers' returns.

Accordingly the study proposed the following recommendations:

1- Collaboration of farmers union, lending institutions and the State should plan agricultural finance to increase the abilities of the small poor farmers at low interest rate, easy terms of repayment, simple procedures in obtaining credit and encouragement of effective use of loans by the farmers.

2- Relevant policies may include reducing production costs or interventions to purchase them at reasonable prices and providing agricultural finance through an easy mechanism to enhancing farmers for achieving harvests.

3- Raising the tenant's awareness about the importance saving will enable the tenants to improve their resources use and significantly increase their farm returns.

4- Application of Islamic financial system in agricultural credit can be preferred due to its low transaction cost and characterized as joint account in cost and profit (i.e. 'mudarbat', 'musharakat'). However, 'selem' also can take a great handling in the credit market as Islamic mode because it can be acceptable price (market price) and incase of season failure, it provides compensation; while it prevents the loan of credit institution in the same time.

\section{ACKNOWLEDGMENTS}

I am thankful to Alla Almighty for the health and the strength to conduct this study. I express my deep appreciation to my colleagues Prof. Hamid H. M. Faki, Abubkr Hussein for their valuable assistance and comments during the course of the study. I am indebted and grateful to the Agricultural Economics and Policy Research Center and Ministry of Agriculture and Irrigation in Sudan for their great encouragement during the study period.

\section{REFERENCES}

[1] Babiker, M. A., 2002, Impact of Agricultural Credit on Crop Productivity in Mechnized rainffed Sub-sector with Emphasis on El Gadarif Area Unpublished. M. Sc. thesis, Faculty of Economic and Rural Development University of Khartoum

[2] Elfeil, M.A., 1993, Economic Constraints of Agricultural Production in the Northern Province of Sudan. An Economic Approach. Unpublished Ph.D. Thesis, University of Khartoum

[3] Faki, H. H., Osman, A., Abdelfatah, A., Elsir, A., Eldekhairy, I., Badwie, A., AboNaof, M., Hussein, A., Ebaid, H., 2003, Agricultural Finance in Sudan, Present Challenges and Future Prospects. Workshop Paper .Khartoum, August, 2003

[4] FAO/WFP, 2005, An FAO/WFP Food Assessment Mission visited both northern and Southern Sudan during the period 8 October - 6 December 2005 and prepared a report on the food needs in Sudan for the year

[5] Ijami, A. A., 1994, Efficiency and Equity Effects of Market Access on Agricultural Productivity in Sudan. A case Study of Small holders Along the River Nile, North Khartoum. Köster Vardjag Press

[6] Ruben G. Echeverria and Nienke M. Beintema, 2009, Mobilizing Financial Resources for Agricultural Research in Developing Countries, Trend and Mechanisms 